Papers and Proceedings of the Royal Society of Tasmania, Volume, 117, 1983.

(ms. received 18.6 .1982 )

\title{
LIVER FLUKE INFECTION IN NORTHWESTERN TASMANIA
}

\author{
by David Obendorf and Tom Black \\ Tasmanian Department of Agriculture, \\ Mt Pleasant Laboratories, \\ Launceston South, Tasmania.
}

A STRACT

OBENDORF, D. \& BLACK, T., 1983 (31 viii): Liver fluke infection in northwestern Tasmania. Pap. Proc. R. Soc. Tasm., 117: 1-3. https://doi .org/10.26749/rstpp.117.1

ISSN 0080-4703. Tasmanian Department of Agriculture, Mt Pleasant

Laboratories, Launceston South, Tasmania.

In 1979, liver fluke, Fasciola hepatica was reported in home-bred cattle, grazing coastal country at Mt Cameron west. Subsequent investigations confirmed the presence of the obligate intermediate host snail. Austropeplea tomentosa, in the draining water system and the presence of liver fluke in the herbivorous macropod, Thylogale bizlardierii. The infection, the first recorded in northwestern Tasmania, further supports observations that marsupials may act as reservoirs of liver fluke.

\section{INTRODUCT ION}

Fasciola hepatica is a common and widespread parasite of the temperate wet agricultural areas of southeastern Australia, wherever the habitat is suitable for the snail intermediate host, Austropeplea tomentosa (Boray 1969). In Tasmania, Austropeplea tomentosa represents the sole intermediate host for liver fluke. This freshwater snail is widely distributed in the river systems of the North and South Esk, in the central highlands, the Derwent Valley and the rivers draining into the east coast (Boray 1964). It is considered to be an endemic Tasmanian snail (Kershaw, pers. comm.). Liver fluke is reported in all these abovementioned agricultural areas. Significantly, infection is not known from the farm lands of northwestern Tasmanian (west of Devonport) or King Island.

From distribution studies of Austropeplea tomentosa collated by Boray (1964) and Smith and Kershaw (1980), the snail has been reported from locations not included in the recognised enzootic fluke areas. These include reports from the Stanley municipality and King Island (Petterd 1889). In addition, A. tomentosa (syn. Amphipeplea Zauncestonensis) is reported in fossil deposits from the Mowbray Swamp, near Smithton (Gill and Banks 1956).

This paper records the occurrence of $A$. tomentosa at a location in northwestern Tasmania and reports the existence of liver fluke infection in both cattle and a species of macropodid marsupial. The origin and maintainance of liver fluke at this site is also discussed.

\section{RESULTS AND DISCUSSION}

Until recently, fascioliasis was not thought to occur in northwestern Tasmania. In 1979 , an $80 \%$ prevalence of liver fluke was recorded in young home-bred cattle which had grazed the coastal heath country at Mt Cameron West (1at. $40^{\circ} 52^{\prime} \mathrm{S}$, long. $144^{\circ} 43^{\prime} \mathrm{E}$ ). Records of the pastoral company which uses this country show that sheep, the main definitive host for liver fluke, grazed the area 18 to 20 years ago. These sheep were brought at sale and the possibility exists that they may have been infected with liver fluke.

During the spring of 1981, searches of the freshwater soaks and pondages in the heathlands behind the established dune of the Mt Cameron area, confirmed the presence of large numbers of Austropeplea tomentosa. Squash preparations of several gastropods and internal organs of the snail revealed numerous cercarial stages in each snail.

Although it is well known that cattle may harbour liver fluke, they are considered secondary or even aberrant hosts (Jubb and Kennedy 1970; Blood et al. 1980). The host inflammatory response to migrating immature fluke and to adults in the bile ducts is 
severe (Jubb and Kennedy 1970). These factors combined with the strong degree of resistance to re-infection suggests that the contribution of cattle to pasture contamination is poor.

The presence of an infected, breeding population of lymneiid snails coupled with the long absence of the preferred definitive host, the sheep, suggested that marsupial herbivores may be of importance in the maintenance of the infectivity of the area for cattle. Unfortunately, there was no opportunity to assess the fluke egg contamination caused by the infected cattle. Most of the cattle were slaughtered. The acquisition of the area by the Tasmanian Government for an aboriginal relics reserve has also prevented any Euture investigations of the cattle infection.

The susceptibility of marsupial herbivores to liver fluke infection is well recognized (McManus 1979; Spratt and Presidente 1981). In Tasmania, liver fluke infection is reported in the forester, Macropus giganteus tasmaniensis, Bennett's wallaby, M. rufogriseus, the red-bellied pademelon. Thylogale bizlardieri, the common wombat, Vombatus ursinus, and the brush-tailed possum, Trichosurus vulpecula (McManus 1979). It is generally accepted that the parasite has been introduced with domestic herbivores, particularly sheep. Marsupial infection has occurred as a result of grazing environments becoining contaminated by livestock and made infective by transmission through the intermediate host snail.

In November 1981, seven red-bellied pademelons were shot at Mt Cameron West. This species was judged to be the predominant macropod in the area. Two were infected with F. hepatica. Mature egg-producing fluke were recovered from both livers. Both infected livers were severely distorted with extensive fibrosis and typical cystic bile ducts. Both infected pademelons were passing liver fluke ova in their faeces, the more heavily parasitised animal at a rate of 70 eggs per gram of faeces.

Taking into account the collection time (November) and the absence of migration tracts caused by immature fluke in the livers of some juvenile pademelons, the infection was probably acquired in previous autumn and winter periods.

It is known that both Bennett's wallabies and red-necked pademelons may harbour up to 80 mature flukes and pass up to 900 fluke eggs per gram of faeces. At this heavy infection rate however, winter mortality would be expected (Presidente, pers. comm.). Lighter infections may well be tolerated with limited impairment to the host and thereby represent a continuous contamination threat.

The liver fluke occurrence at Mt Cameron West may have represented a situation where macropods acted as the predominant host for liver fluke and the source of infection for cattle, after the sheep were removed. Preliminary investigations suggest that this location represents an isolated focus of liver fluke. The water system is a closed one draining the surrounding wooded dunes and flowing into the sea.

The suggestion that macropods act as reservoirs of liver fluke has been stated previously (McManus 1979). Such fluke infections in macropods may represent a significant problem in the control of liver fluke in domestic livestock. A similar situation at Tidbinbilla Nature Reserve has been reported (Spratt and Presidente 1978). At that particular locality, liver fluke is maintained by the eastern grey kangaroo, Macropus giganteus, in the absence of domestic animal hosts.

\section{ACKNOWLEDGEMENTS}

The authors wish to thank Dr Brian Smith, National Museum of Victoria for identifying the snails collected at Mt Cameron West and Mr Ron Kershaw, Honorary Associate of the National Museum of Victoria, for information on the distribution of Austropeplea tomentosa in northwestern Tasmania. The assistance of the National Parks and Wildlife Service is also gratefully acknowledged. 
David Obendorf and Tom BTack

REFERENCES

Blood, D.C., Henderson, J.A. and Radostits, O.M., 1980: VETERINARY MEDICINE, 5th Ed., Baillière Tindall, London.

Boray, J.C., 1964: Studies on the ecology of Lymaea tomentosa, the intermediate host of Fasciola hepatica. Aust. J. Zool., 12: 217-230.

, 1969: Experimental fascioliasis in Australia. Adv. Parasitol., 7: 95-210.

Gill, E.D. and Banks, M.R., 1956: Cainozoic history of Mowbray Swamp and other areas of northwestern Tasmania. Rec. Q. Vic. Mus., New Ser. 6: 1-42.

Jubb, K.V.F. and Kennedy, P.C., 1970: PATHOLOGY OF DOMESTIC ANIMALS, 2nd Ed. Academic Press, New York, London.

McManus, T.J., 1979: Native fauna and liver fluke. J. Agric. Tasm., 50: 43-45.

Petterd, W.F., 1889: Contributions for a systematic catalogue of the aquatic shells of Tasmiania. Pap. Proc. R. Soc. Tasm., 1888: 60-83.

Presidente, P.J.A., 1978: Diseases seen in free-ranging marsupials and those held in captivity. In "Fauna - Part B". Post Grad. Comm. Vet. Sei., Proc. 36: 457-471.

Smith, B.J. and Kershaw, R.C., 1981: FAUNA OF TASMANIA HANDBOOK NO.5. TASMANIAN LAND AND FRESHWATER MOLLUSCS. Ist Ed. University of Tasmania, Hobart.

Spratt, D.M. and Presidente, P.J.A., 1981: Prevalence of Fasciola hepatica infection in native animals in south-eastern Australia. Aust. J. Exptz Biol. Med. Sci., 59: $713-721$.

\section{POSTSCRIPT}

Since this article was written another site of liver fluke infection has been investigated at Sandy Cape (lat $41^{\circ} 25^{\prime}$, , long. $\left.144^{\circ} 45^{\prime} \mathrm{E}\right)$. A. tomentos $\alpha$ containing developing stages of $F$. hepatica were found in two water systems with similar aquatic habitats to those at Mt Cameron West. The macropodid species, M. r. mfogriseus and T. bizlardierii were found to harbour fluke infections at Sandy Cape. Introduction of liver fluke by domestic herbivores is again possible since this coastal area is used for livestock agistment. 